\title{
ЛОГІСТИЧНІ ПІДХОДИ В УПРАВЛІННІ МЕРЕЖЕЮ ОБЛАСНИХ МЕДИЧНИХ УСТАНОВ В УМОВАХ РЕФОРМИ
}

\author{
Михальчук В. М., Коломосць А. В.
}

\section{ВСТУП}

Шлях реформування системи охорони здоров'я досить тривалий та вимагає усунення безлічі проблем, що виникли в українській системі охорони здоров'я. Практика діяльності медичних установ засвідчує, що суттєвими проблемами, які нині перешкоджають розвитку суб'єктів медичної сфери, виступають проблеми нераціонального розподілу ресурсів між медичними установами й несумісності економічних інтересів між медичними установами й клієнтами їхніх послуг.

У контексті вирішення зазначених проблем велика перевага надається застосуванню вітчизняних систем менеджменту, які демонструють логічні й чіткі способи мислення. Важливого значення водночас набувають саме логістичні підходи, використання яких дозволить не тільки ефективно управляти діяльністю медичних установ, але й сприятиме досягненню соціальної захищеності населення та підвищення належного рівня і якості життя.

Таким чином, актуальність тематики цієї наукової статті зумовлена окресленими вище проблемами й полягає в дослідженні логістичних підходів в управлінні діяльністю медичних установ.

Дослідження логістичних підходів в управлінні діяльністю медичних установ і закладів охорони здоров'я проводили такі відомі вчені, як Л. Ю. Бабінцева, С. В. Барнатович, І. Д. Бенько, В. С. Бенько, Ю. В. Вороненко, Н. Г. Гойда, І. С. Зозуля, Т. П. Іванова, О. С. Каневський, В. М. Кислий, Н. В. Котис, Є. Є. Латишев, М. М. Лугін, В. М. Михальчук, Н. В. Ольхович, Я. Г. Онищенко, 3. В. Гбур, О. В. Посилкіна, Р. В. Сагайдак-Нікітюк , С. В. Сисюк, І. Ю. Скирда, В. 3. Стецюк, І. С. Ткачук, В. П. Філіпішин, О. Д. Фіногенов, Р. В. Ціщик, М. Б. Щербиніна та інші науковці.

Метою статті виступає дослідження логістичних підходів в управлінні мережею обласних медичних установ в умовах реформи. 


\section{1. Зміст та особливості поняття "логістики" в медицині}

У рамках розкриття тематики наукової статті доцільно насамперед 3'ясувати зміст і особливості поняття “логістика” в контексті управління медичними установами.

Незважаючи на те, що поняття “логістика" відносно новий економічний термін, історія його вживання досить багатовікова. Так, у Стародавній Греції під логістикою розглядали систему державного контролю щодо виконання загальнодержавних розрахунків. Водночас у Стародавньому Римі в зміст логістики вкладали процедуру розподілу продовольства ${ }^{1}$.

У наш час термін “логістика” трактується переважно з позиції трьох підходів ${ }^{2}$ :

1) як напрям господарської діяльності щодо управління матеріальними потоками сфер виробництва й обігу задля поставки ресурсів в обумовлені строки;

2) як підприємницька концепція, що відображає стратегічні орієнтири розвитку бізнесу;

3) як міждисциплінарний науковий напрям пошуку потенційних можливостей покращення ефективності матеріальних потоків.

Дослідження засвідчують, що використання логістики в сфері охорони здоров'я відбулося недавно.

Що стосується логістики в медицині, то під цим поняттям Р. В. Ціщик пропонує розуміти процес безпосереднього планування, управління та контролю ефективності логістичних потоків, а також транспортування та зберігання лікувальних засобів і медичних виробів ${ }^{3}$.

На основі досліджень можна стверджувати, що саме логістичні підходи виступають одним із перспективних напрямків організації матеріального забезпечення обласних медичних установ.

Виходячи $з$ цього слід зауважити, що логістика не тільки здатна керувати процесами постачання, але також однією 3 іiі важливих функцій виступає проведення ефективного лікувально-діагностичного процесу.

1 Каневський О. С., Кислий В. М., Ткачук I. С. Передумови застосування логістичних підходів у галузі медицини. Медицина транспорту Украйни. 2005. № 5. C. 22-29.

2 Каневський О. С., Кислий В. М., Ткачук І. С. Передумови застосування логістичних підходів у галузі медицини. Медицина транспорту Украӥни. 2005. № 5. C. $22-29$.

3 Ціщик Р. В. Аналіз застосування інноваційних логістичних підходів до діяльності медичних установ. Приазовський економічний вісник. 2019. Випуск 4 (15). С. $168-172$. 
Також слід відмітити й те, що завдяки логістиці медичний персонал повністю може сконцентрувати свою увагу на задоволенні потреб споживачів медичних послуг. Особливе місце в даному контексті посідає оптимізація роботи медичного персоналу, яка не лише підвищить ефективність його діяльності, але й дозволить скоротити рівень відходів у ланцюгах поставок і запропонує можливість надавати якісні медичні послуги відповідно до потреб клієнтів.

Ключовими сферами логістичного управління в галузі охорони здоров'я виступають ${ }^{4}$ : сфера біомедичної інженерії; сфера клінічної інженерії; фармацевтична сфера; сфера медичних послуг; персонал медичних установ (закладів).

Завдяки процесам поставки медичного майна в належній кількості, в належний час і в належне місце чітко можна визначити ефективність логістичних дій. Враховуючи зазначене, потрібно наголосити на таких перспективних позиціях логістики в управлінні медичними установами ${ }^{5}$ :

- правильність обрання відповідного логістичного підходу вказує на ефективність його здійснення (так, наприклад, не можна знижувати обсяги запасів медичного майна, оскільки це може призвести до виникнення різних дефектів у лікувально-діагностичному процесі);

- контроль за раціональністю розподілу медичного майна тепер виступає особливим інструментом логістики;

- стрімкі темпи науково-технічного розвитку чинять неабиякий вплив на об'єднання цілей логістичної концепції в єдиному напрямку;

- завдяки логістичним процесам можна не тільки вирішити поставлені завдання, але й сформувати цілісну стратегію забезпеченості медичних установ необхідним медичним майном;

-з метою мінімізації витрат на логістичні процеси постачання рекомендується здійснювати функціонально-вартісний аналіз застосовуваних процедур.

На основі проведених досліджень з'ясовано, що в процесі реалізації логістичної концепції управління медичною установою необхідно керуватись відповідними принципами, серед яких важливе місце посідають наступні ${ }^{6}$ :

4 Ціщик Р. В. Аналіз застосування інноваційних логістичних підходів до діяльності медичних установ. Приазовський економічний вісник. 2019. Випуск 4 (15). C. $168-172$.

5 Філіпішин В. П. Застосування логістичних підходів у роботі лікувальнопрофілактичних закладів. Проблеми військової охорони здоров'я. 2015. Випуск 43. C. 16-23.

${ }^{6}$ Котис Н. В., Ціщик Р. В. Аналіз доцільності запровадження логістичного менеджменту в діяльності закладів охорони здоров'я. Інфраструктура ринку. 2019. Випуск 33. С. 178-183. 
1) принцип цілісності (відображає здатність логістичної системи виконувати поставлені перед нею функції загалом, а не окремими частинами);

2) принцип системності (характеризує дослідження логістичного об'єкта як підсистеми, що ефективно взаємодіє з іншими підсистемами управлінського процесу);

3) принцип раціональності (відображає прийняття кращих управлінських рішень внаслідок оцінювання витрат та отриманих результатів);

4) принцип формалізації (характеризує якісні й кількісні особливості управлінського процесу на засадах використання системного аналізу);

5) принцип формування (реалізується через використання системного підходу в управлінні, елементи якого взаємопов'язані та націлені на досягнення спільної мети);

6) принцип інтеграції (відображає вивчення властивостей i закономірностей управлінського процесу й об'єднання їх в єдине ціле);

7) принцип ієрархії (демонструє порядок переходу процесу управління від вищого до нижчого рівня управління).

Окрім зазначених вище основних принципів, в рамках логістичного управління матеріальними ресурсами медичних установ слід також керуватись і такими ${ }^{7}$ :

- принцип гуманізації технологічних процесів;

- принцип адаптації до умов невизначеності середовища функціонування;

- принцип поєднання процесу управляння матеріальними ресурсами 3 інформаційним потоком.

Поряд з тим, особами, від дій яких залежить процес та особливості прийняття логістичних рішень у контексті управління медичними установами, $є$ клієнти медичних установ (споживачі медичних послуг), постачальники й виробники медичної продукції, транспортні агенти, посередники, урядові організації.

${ }^{7}$ Вороненко Ю. В., Гойда Н. Г., Зозуля І. С., Латишев Є. Є., Михальчук В. М. Сучасні підходи до управління матеріальними ресурсами медичного закладу. Український медичний часопис. 2013. № 1. С. 19-22.

${ }^{8}$ Вороненко Ю. В., Гойда Н. Г., Зозуля І. С., Латишев Є. Є., Михальчук В. М. Сучасні підходи до управління матеріальними ресурсами медичного закладу. Украӥнський медичний часопис. 2013. № 1. С. 19-22. 


\section{2. Особливості логістичної концепції управління медичною установою}

Спираючись на результати дослідження ${ }^{9}$, доцільно виділити такі ключові особливості логістичної концепції управління медичною установою:

1) високий рівень виробничої інтеграції;

2) висока якість надання медичних послуг і їх адаптація до потреб ринку;

3) оптимізація комплексу процесів;

4) інтенсивне використання виробничих потужностей;

5) універсальність обладнання;

6) зниження кількості послуг, які не користуються попитом;

7) зниження тривалості здійснюваних логістичних операцій;

8) підвищення гнучкості й мінімізація технологічних циклів через зниження надлишків товарних та матеріальних запасів.

Колектив науковців на чолі з О. С. Каневським ${ }^{10}$, поділяючи думку Є. В. Сайникова, наголошує на поділі матеріального-технічного забезпечення медичних установ за рахунок двох логістичних підходів макрологістики та мікрологістики.

3 огляду на вищеозначене, основними проблемами, які належить вирішити в рамках макрологістики, $є$ :

a) проблеми оптимізації технологічних $\mathrm{i}$ технічних структур медичних установ за рахунок використання автоматизованих технічних систем;

б) проблеми визначення рівня попиту й пропозиції на майно медичних установ внаслідок створення стратегічного плану діяльності логістичних систем;

в) проблеми вивчення стану та стійкості функціонування логістичних систем;

г) проблеми комплексної оптимізації транспортування і поділу майна медичних установ.

Поряд 3 тим основними завданнями мікрологістики виступають:

a) формування рівноваги між обсягами складування і обсягами перевезень медпрепаратів та обладнання;

9 Філіпішин В. П. Застосування логістичних підходів у роботі лікувальнопрофілактичних закладів. Проблеми військової охорони здоров'я. 2015. Випуск 43. C. $16-23$.

10 Каневський О. С., Кислий В. М., Ткачук І. С. Передумови застосування логістичних підходів у галузі медицини. Медищина транспорту України. 2005. № 5. C. $22-29$. 
б) скорочення суми витрат i видатків у випадку відмови чи простою;

в) визначення оптимального рівня взаємодії між процесами отримання, зберігання та транспортування;

г) раціоналізація структури інформаційних потоків в управлінській системі ${ }^{11}$.

3'ясовано, що логістична система в медичних установах складається 3 фізичної підсистеми, яка відображає потік матеріалів безпосередньо із складу до споживача, та підсистеми забезпечення руху ресурсів від постачальників до складів.

Деталізуючи вищенаведене варто зауважити, що основними елементами системи медичного постачання виступають ${ }^{12}$ :

1) виробничі запаси (забезпечують рівномірність функціонування складських структур);

2) транспорт (як засіб перевезення майна від постачальників до складів);

3) обслуговування (сприяє визначенню потреб та забезпечує досягнення рівноваги між попитом і пропозицією на відповідні запаси);

4) складське господарство (до складу якого належать засоби завантаження та складування, складські приміщення);

5) інформаційний зв'язок i контроль (забезпечують належний рівень запасів, сприяють передачі замовлень і вимог на відвантаження).

У рамках реформування системи охорони здоров'я необхідно керуватись насамперед інформацією про попит та пропозицію на медичні вироби й лікарські засоби, використовуючи водночас надані ресурси й обсяги фінансування. Поряд з тим, потрібно врахувати й той факт, наскільки якісні послуги, що надаються медичними установами.

М.Б. Щербиніна та I.Ю. Скирда вважають, що найбільш оптимальним в умовах реформи охорони здоров'я є процесний підхід до управління медичними установами. Через процесний підхід діяльність медичних установ розглядається як задана послідовність ланцюгових операцій, кінцевим результатом яких виступає досягнення клініко-економічного ефекту. Застосування процесного підходу до управління медичними установами вимагає не лише зміни концепції

11 Каневський О. С., Кислий В. М., Ткачук І. С. Передумови застосування логістичних підходів у галузі медицини. Медицина транспорту Украӥни. 2005. № 5. C. $22-29$.

12 Каневський О. С., Кислий В. М., Ткачук І. С. Передумови застосування логістичних підходів у галузі медицини. Медицина транспорту Украӥни. 2005. № 5. C. 22-29. 
мислення керівників та працівників цих установ, але й врахування всіх елементів якості, адресованих клієнтам системою менеджменту ${ }^{13}$.

Процесний підхід в управлінні медичними установами орієнтований також на залучення працівників не тільки до удосконалення виробничих процесів, але й до усіх без винятків видів діяльності цих установ. Адже нині суб'єкти господарювання медичної сфери орієнтуються на інноваційний тип управління.

Дослідження доводять, що під час проектування логістичних процесів в управлінні медичними установами потрібно застосовувати структурний підхід до управління. Суть цього підходу полягає в розмежуванні управлінських функцій між конкретними особами. Проте в рамках застосування структурного підходу виникає недолік невідповідності організаційної структури управління раціональній структурі управління медичними установами ${ }^{14}$.

У випадку застосування процесного підходу до управління медична установа являє собою цілісну систему взаємопов'язаних між собою бізнес-процесів. А це створює необхідність переходу на використання ресурсозберігаючої структури управління ${ }^{15}$.

Думки щодо застосування інноваційних логістичних підходів в управлінні медичними установами також притримується і Р.В. Ціщик. Науковець зазначає, що втілення логістичних підходів у практику діяльності медичних установ дозволить ${ }^{16}$ :

1) розробити таку структуру медичної установи, результати діяльності якої задовольнятимуть потреби її клієнтів;

2) сформувати оптимальну систему фінансування діяльності медичних установ 3 метою досягнення рівноваги між обсягами й структурою медичних послуг;

3) розподілити ресурси між медичними установами у відповідності до їхніх потреб та можливостей;

4) ефективно управляти медичними установами, виходячи 3 доступності достовірної та релевантної інформації;

5) скоротити рівень витрат внаслідок впровадження ефективних лікувально-діагностичних процесів.

${ }^{13}$ Щербиніна М. Б., Скирда І. Ю. Формування та розвиток структурно-процесної організації в медичних установах. Гастроентерологія : збірник наукових праць. 2012. № 46. C. 48-56.

${ }^{14}$ Ibid

${ }^{15}$ Ibid.

16 Ціщик Р. В. Аналіз застосування інноваційних логістичних підходів до діяльності медичних установ. Приазовський економічний вісник. 2019. Випуск 4 (15). C. $168-172$. 
У рамках застосування логістичних функцій до діяльності медичної установи можна дізнатися деяку інформацію про наявні в ній запаси. Отже можна встановити обсяг запасів, термін їх придатності й термін їх скінченності, визначити вартість зберігання та ринкову вартість ${ }^{17}$.

Разом з тим інформація про рівень споживання матеріальних запасів i його зміни буде корисною та необхідною для підвищення ефективності їх використання. Адже потрібна структура та обсяги матеріальних запасів завжди забезпечують потреби медичних установ. Водночас рівень ефективності використання матеріальних запасів залежить від такої рівноваги: наявні матеріальні запаси мають бути мінімальними, однак у повному обсязі повинні задовольняти потреби медичної установи в рамках безперебійного й успішного функціонування ${ }^{18}$.

Нині нагального вирішення потребує також проблема мінімізації відходів у фармацевтичній сфері. 3 метою ефективного використання матеріальних ресурсів і водночас зниження відходів доцільно створити спеціальний логістичний центр у кожному 3 регіонів, який спеціалізуватиметься на переробці, утилізації та знищенні відходів ${ }^{19}$.

Корисним такий центр буде й для медичних установ, оскільки, маючи інколи в наявності неякісну й небезпечну фармацевтичну продукцію, вони можуть отримати штрафи за несанкціоноване зберігання такої продукції. Отже, співпрацюючи з таким центром через відповідні логістичні ланцюги, медичний заклад позбувається цієї небажаної фармацевтичної продукції.

Для того щоб підвищити рівень сервісу й водночас знизити витрати в секторі охорони здоров'я, медичним закладам слід активно використовувати логістичні підходи до управління ланцюгами постачання. Основними завданнями логістичного менеджменту $є$ інтеграція логістичних підприємств і логістичної інформації (про транспортні засоби, ситуацію на дорогах, транспортування, складування та зберігання медичного обладнання, ліків, медичної техніки) на одній платформі, а

${ }^{17}$ Бенько І. Д., Бенько В. С. Оцінка ефективності системи управління запасами медичних установ: українська та світова практика. Всеукраӥнський наукововиробничий журнал “Інноваційна економіка". 2013. Випуск 1. С. 200-203.

${ }^{18}$ Бенько I. Д., Сисюк С. В. Аналіз запасів медичних установ. Всеукрайнський науково-виробничий журнал “Інновачійна економіка”. 2013. Випуск 1. С. 267-270.

19 Посилкіна О. В., Сагайдак-Нікітюк Р. В., Онищенко Я. Г. Управління утилізацією відходів у фармацевтичній галузі на логістичних засадах. Запорожский медииинский журнал. 2009. № 3. С. 120-124. 
також комплексний централізований аналіз із запровадженням диспетчеризації транспортних засобів, доріг, складів, ліків, медичного обладнання та персоналу для зменшення витрат на зберігання, зниження вартості логістики й підвищення ії ефективності ${ }^{20}$.

У діяльності закладів охорони здоров'я сукупність процесів та подій представлена у вигляді руху матеріальних, фінансово-кредитних, інформаційних, людських потоків.

Для управління потоковими процесами використовуються певні підходи (табл. 1).

Таблиця 1

Логістичні підходи для управління потоковими процесами в закладах охорони здоров'я

\begin{tabular}{|c|c|}
\hline Підходи & Зміст \\
\hline Операційне управління & $\begin{array}{l}\text { Забезпечує виконання всіх робочих процесів } 3 \\
\text { мінімальними загальними затратами - } \\
\text { затрати на виробництво, включаючи закупку } \\
\text { матеріальних ресурсів, збут та просування } \\
\text { медичних послуг }\end{array}$ \\
\hline $\begin{array}{l}\text { "Точно в строк" } \\
\text { (just-in-time) }\end{array}$ & $\begin{array}{l}\text { Підпорядкування організації, планування та } \\
\text { управління у всіх сферах виробничої } \\
\text { діяльності принципу все закуповувати, } \\
\text { виробляти та відпускати споживачу “точно в } \\
\text { строк” }\end{array}$ \\
\hline $\begin{array}{l}\text { Диспетчеризація потокових } \\
\text { процесів }\end{array}$ & $\begin{array}{l}\text { Підвищує швидкість та точність пересування } \\
\text { конкретного споживача медичної послуги в } \\
\text { процесі ії виробництва за рахунок } \\
\text { використання сучасних комп’ютерних } \\
\text { технологій }\end{array}$ \\
\hline $\begin{array}{l}\text { Моніторинг та оцінка } \\
\text { матеріальних потоків, } \\
\text { організація їх регулювання } 3 \\
\text { моменту входження у } \\
\text { виробничий цикл до } \\
\text { остаточного використання в } \\
\text { ньому аж до кінцевого } \\
\text { споживача медичних послуг }\end{array}$ & $\begin{array}{l}\text { Зміцнює зв’язок медичного закладу з } \\
\text { постачальниками матеріальних ресурсів }\end{array}$ \\
\hline
\end{tabular}

${ }^{20}$ Вороненко Ю. В., Гойда Н. Г., Зозуля І. С., Латишев Є. Є., Михальчук В. М. Сучасні підходи до управління матеріальними ресурсами медичного закладу. Український медичний часопис. 2013. № 1. С. 19-22. 
Закінчення таблиці 1

\begin{tabular}{|c|c|}
\hline Цільова установка & $\begin{array}{l}\text { Орієнтація на потреби окремих пацієнтів, } \\
\text { корпоративних клієнтів, розвиток договірних } \\
\text { відносин з великими та малими замовниками } \\
\text { медичних послуг }\end{array}$ \\
\hline $\begin{array}{l}\text { Розвиток горизонтальних } \\
\text { взаємовідносин між } \\
\text { закладами охорони здоров'я }\end{array}$ & $\begin{array}{l}\text { Виникає в результаті вимушеної конкуренції } \\
\text { один з одним у процесі обслуговування } \\
\text { споживачів під час намагання максимально } \\
\text { підвищити якість свого медичного продукту } \\
\text { й втрачання для цього мінімальних засобів, } \\
\text { що призводить до спрощення (набуття } \\
\text { горизонтального характеру) багаторівневих } \\
\text { ієрархічних структур управління }\end{array}$ \\
\hline Впровадження інновацій & $\begin{array}{l}\text { Безперервне впровадження інноваційної } \\
\text { логістики з оцінкою наслідків прийнятих } \\
\text { рішень, їх вплив на функціональні затрати, на } \\
\text { доходи від продажів медичних послуг для } \\
\text { досягнення медичним закладом конкурентної } \\
\text { переваги }\end{array}$ \\
\hline
\end{tabular}

Джерело: складено автором на основі досліджень

Важливо зазначити, що продуманий операційний менеджмент залежить від строго вибудуваної структури закладу охорони здоров'я та чіткої організації діяльності всіх частин цієї структури, що, в кінцевому підсумку, впливає на поліпшення ефективності роботи закладу. Ідеальний менеджмент медичного закладу - це процес, керівництво якого не тільки володіє навичками в галузі медицини, але й має уявлення про те, як правильно управляти персоналом. Якісний менеджмент $\epsilon$ основою для хорошого доходу компанії. Саме тому до приватних закладів охорони здоров'я варто ставитися насамперед як до бізнесу, а значить, використовувати класичні технології управління ${ }^{24}$.

21 Барнатович С. В. Формування логістичної моделі управління діяльністю комунальних фармацевтичних підприємств в умовах менеджменту якості: автореф. дис. ... канд. фармац. наук : 15.00.01 ; Національний фармацевтичний університет. Хмельницький, 2011. 22 с.

${ }^{22}$ Бенько І. Д., Бенько В. С. Оцінка ефективності системи управління запасами медичних установ: українська та світова практика. Всеукраӥнський наукововиробничий журнал “Інноваційна економіка”. 2013. Випуск 1. С. 200-203.

23 Національна стратегія реформування системи охорони здоров'я в Україні на період 2015-2020 років. Управління охорони здоров'я Чернісівської обласної державної адміністрації : вебсайт. URL: http://uoz.cn.ua/strategiya.pdf (дата звернення: 15.02.2020).

${ }^{24}$ Бенько I. Д., Сисюк С. В. Аналіз запасів медичних установ. Всеукраӥнський науково-виробничий журнал “Інновачійна економіка”. 2013. Випуск 1. С. 267-270. 


\section{3. Модель логістичного процесу}

Спираючись на зазначене вище, а також враховуючи наукові праці ${ }^{25}$, логістичний процес обігу лікарських засобів та медичних виробів в обласній медичній установі можна зобразити у вигляді рис. 1.

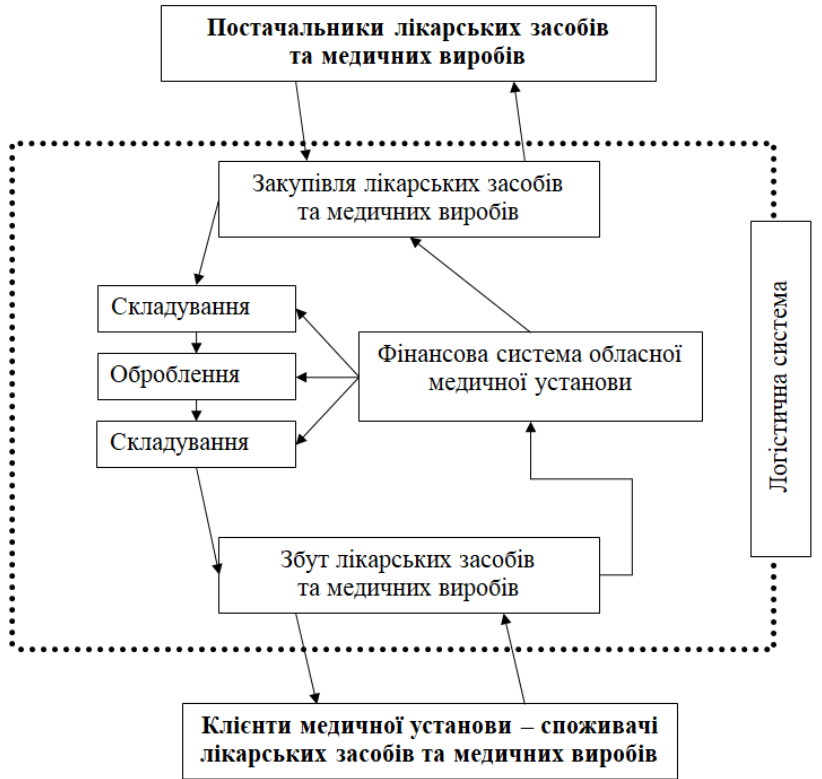

\section{Рис. 1. Логістичний процес обігу лікарських засобів та медичних виробів в обласній медичній установі}

C.В. Барнатович у дисертаційному дослідженні ${ }^{26}$ розробила логістичну процесну модель управління рухом товарів на об'єктах системи охорони здоров'я. Так, основними під-системами цієї моделі вбачаються маркетинг, закупка, складування, розподіл та доставка замовлень. За такої умови постачальними під-процесами виступають

${ }^{25}$ Каневський О. С., Кислий В. М., Ткачук І. С. Передумови застосування логістичних підходів у галузі медицини. Медицина транспорту України. 2005. № 5. C. 22-29.

26 Барнатович С. В. Формування логістичної моделі управління діяльністю комунальних фармацевтичних підприємств в умовах менеджменту якості: автореф. дис. ... канд. фармац наук : 15.00.01 ; Національний фармацевтичний університет. Хмельницький, 2011. 22 с. 
процеси управління запасами, процеси управління інфраструктурою, процеси управління метрологічним забезпеченням, процеси управління персоналом, процеси управління документацією та процеси управління виробничим середовищем ${ }^{27}$.

Отже, внаслідок інтерпретації моделі, розробленої С.В. Барнатович, на рис. 2 представлено логістичну модель управління потоком лікарських засобів та медичних виробів в діяльності обласної медичної установи.

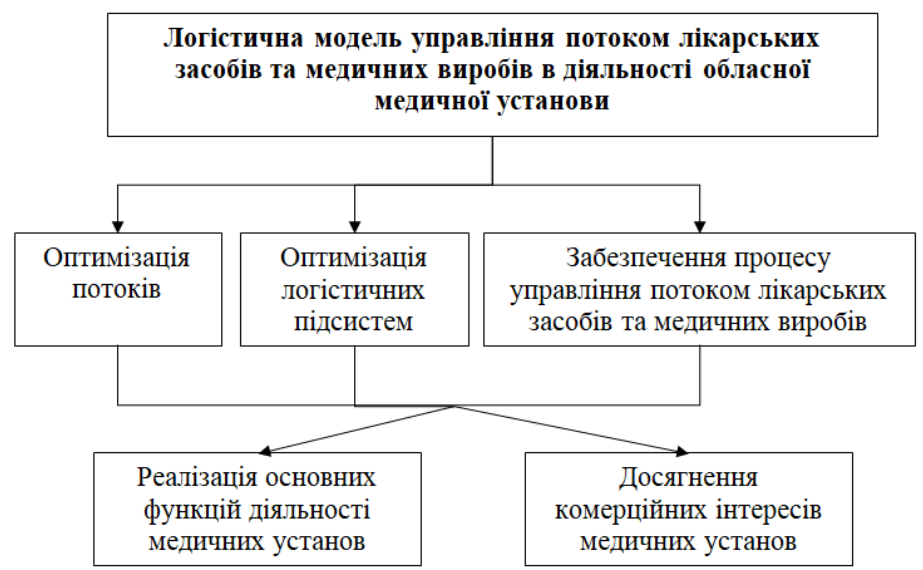

\section{Рис. 2. Логістична модель управління потоком лікарських засобів та медичних виробів в обласній медичній установі}

Колектив науковців на чолі 3 В. 3. Стецюком ${ }^{28}$ у контексті управління медичними установами пропонує використовувати Enterprise Resource Planning систему (систему планування ресурсів підприємства) (далі - ERP-система) для медичних установ. Суть ERPсистеми полягає в тому, що вона охоплює всі ключові процеси, що відбуваються в діяльності медичних установ.

27 Барнатович С. В. Формування логістичної моделі управління діяльністю комунальних фармацевтичних підприємств в умовах менеджменту якості: автореф. дис. ... канд. фармац. наук : 15.00.01 ; Національний фармацевтичний університет. Хмельницький. 2011. 22 с.

${ }^{28}$ Стецюк В. 3., Іванова Т. П., Бабінцева Л. Ю., Ольхович Н. В., Лугін М. М., Фіногенов О. Д. Використання ERP-систем для медичних установ. Медична інформатика та інженерія. 2017. № 4. С. 44-47. 
Стандартний набір функціональних елементів ERP-системи включає такі компоненти:

a) планування виробничих ресурсів;

б) фінансування обліку і планування;

в) управління основними фондами;

г) управління персоналом;

д) товарний облік та управління складськими запасами;

е) управління закупівлями;

є) управління логістичними операціями;

ж) управління маркетинговими заходами;

з) управління процесом оброблення замовлень;

и) управління продажами;

i) управління процесами електронної комерції;

і) бізнес-аналітика;

й) управління проектами;

к) управління конструкторсько-технологічною документацією ${ }^{29}$.

Унаслідок інтерпретації стандартного набору ERP-системи до засад діяльності медичних установ реалізація функцій відбувається вже за такими елементами: реєстраційно-статистичний елемент, лист лікарських призначень, протоколи сестринського догляду, договір щодо надання медичних послуг, диспансерний облік, вакцинопрофілактика, професійні огляди, профілактичні медичні огляди.

Поряд 3 тим варто наголосити, що контроль за логістичними процесами може проводити зовнішня компанія. Однак при виборі такої компанії слід чітко вивчити специфіку ії діяльності, а також те, чи контролювала вона раніше логістичні процеси в сфері охорони здоров'я. Отже, до зовнішніх компаній, що здійснюють контроль за логістичними процесами й безпосередньо беруть у ньому участь, ставляться такі вимоги ${ }^{30}$ :

1) наявність спеціального транспорту для транспортування лікарських засобів та медичних виробів;

2) наявність спеціальних упаковок, що необхідні для додержання відповідних температурних режимів;

3) постійний моніторинг стану замовлень на кожному логістичному процесі;

${ }^{29}$ Стецюк В. 3., Іванова Т. П., Бабінцева Л. Ю., Ольхович Н. В., Лугін М. М., Фіногенов О. Д. Використання ERP-систем для медичних установ. Медична інформатика та інженерія. 2017. № 4. С. 44-47.

30 Ціщик Р. В. Аналіз застосування інноваційних логістичних підходів до діяльності медичних установ. Приазовський економічний вісник. 2019. Випуск 4(15). C. $168-172$. 
4) дотримання норм вітчизняного й міжнародного законодавства в сфері поводження з лікарськими засобами та медичними виробами.

Зі слів регіонального координатора 3 підтримки реформи охорони здоров'я в Закарпатській області $€$. В. Мешка ${ }^{31}$, результат медичної реформи залежить від вдало обраної та впровадженої системи менеджменту, якісно проведеного фінансового аналізу, оптимізації структури органів охорони здоров'я та від того, наскільки ефективні розроблені та впроваджені логістичні процеси.

Як зазначається в Національній стратегії реформування системи охорони здоров'я в Україні на період 2015-2020 років ${ }^{32}$ (далі Національна стратегія), одним 3 напрямків реформування виступає проведення реформи мережі лікарень. Стає відомим той факт, що кількість та структура лікарень в Україні (зокрема й медичних установ) потребує нагальної оптимізації.

Згідно положень Національної стратегії передбачається формування єдиної мережі лікарень (медичних установ) для кожної з областей. Водночас вони будуть об'єднані в єдиний лікарняний простір держави.

У період переходу до ринкової економіки вітчизняна система охорони здоров'я грунтується на принципах сучасної системи менеджменту. За цих обставин інтереси як споживачів, так і осіб, що надають послуги у системі охорони здоров'я, чітко взаємоузгоджені.

\section{ВИСНОВКИ}

Таким чином, в контексті проведеного дослідження проаналізовано й вивчено ряд логістичних підходів до управління мережею обласних медичних установ. 3'ясовано, що саме логістичні підходи виступають одним 3 перспективних напрямків організації матеріального забезпечення обласних медичних установ.

У рамках дослідження розглянуто процесний підхід до управління діяльністю медичних установ, у сутність якого закладена послідовність ланцюгових операцій, кінцевим результатом яких виступає досягнення клініко-економічного ефекту. Встановлено також, що процесний підхід в управлінні медичними установами орієнтований на залучення працівників не тільки до удосконалення виробничих процесів, але й до усіх без винятків видів діяльності цих установ.

${ }^{31}$ Мешко Є. В. Медична реформа: як зміниться “вторинка”. Децентралізація дає можливості : вебсайт. URL: https://decentralization.gov.ua/news/11880. (дата звернення: 15.02.2020).

${ }^{32}$ Національна стратегія реформування системи охорони здоров'я в Україні на період 2015-2020 років. Управління охорони здоров'я Чернігівськоӥ обласної державної адміністрації : вебсайт. URL: http://uoz.cn.ua/strategiya.pdf (дата звернення: 15.02.2020). 
Проведені дослідження засвідчили, що під час проектування логістичних процесів в управлінні медичними установами потрібно також застосовувати структурний підхід до управління, суть якого полягає в розмежуванні управлінських функцій між конкретними особами. Отже варто звернути увагу й на важливості інноваційного логістичного підходу в управлінні медичними установами.

Основними умовами для використання логістичних підходів у закладах охорони здоров'я $\epsilon$ : параметризація потоків медичного закладу та їх моніторинг; визначення закономірностей функціонування виробничого середовища на основі регламенту; визначення пунктів диспетчеризації потоків руху з метою підвищення якості оперативного управління; вибір варіанту рішення на основі співставлення параметрів потоків із станом кадрів, технологій, ресурсів на конкретній ділянці виробничого середовища. Логістика потоків потрібна для планування, реалізації, фінансування та оцінювання ефективності епідеміологічного нагляду, якості, організаційно-технічного рівня послуг. Можна припустити, що запропонований перелік потенційних напрямків застосування логістики в управлінні Комунальним некомерційним підприємством закладом охорони здоров'я не вичерпний. Кожен з них також можна розширити в межах проведеного дослідження.

Окрім того вивчення зарубіжного досвіду доводить, що ефективне управління логістикою неможливе без оперативного інформаційного обслуговування, яке забезпечує швидкий документообіг та формування єдиного інформаційного простору, що сприяє надійній та безперервній роботі медичних установ, допомагає удосконалити потік вантажоперевезень лікарських засобів і медичного обладнання в регіонах.

У свою чергу, медичному персоналу логістика дозволяє повною мірою сконцентруватися на лікуванні й турботі про пацієнтів. Оптимізація, що забезпечує більш ефективну роботу медичного персоналу, скорочення відходів в ланцюгах поставок, надання якісних послуг та вирішення поставлених замовником завдань точно в термін $\epsilon$ пріоритетами застосування принципів логістики в сучасній медицині.

3'ясовано також, що завдяки логістиці можна значно покращити організацію діяльності медичних установ (в тому числі й цілої мережі обласних медичних установ), підвищити рівень культури обслуговування осіб, що звернулися за допомогою до фахівців медичних установ. Такі дії неодмінно сприятимуть вирішенню проблем матеріально-технічного забезпечення і фінансування діяльності цих установ. Побудувавши логістичну модель управління мережею обласних медичних установ, можна вирішити ключові організаційні проблеми, з якими натепер стикається безліч клієнтів цих установ. 


\section{АНОТАЦІЯ}

У статті досліджено та систематизовано логістичні підходи в управлінні мережею обласних медичних установ в умовах реформи. 3'ясовано, що саме логістичні підходи виступають одним з перспективних напрямків організації матеріального забезпечення обласних медичних установ. Розглянуто процесний підхід до управління діяльністю медичних установ, у сутність якого закладена послідовність ланцюгових операцій, кінцевим результатом яких виступає досягнення клініко-економічного ефекту. Встановлено також, що процесний підхід в управлінні медичними установами орієнтований на залучення працівників не тільки до вдосконалення виробничих процесів, але й до всіх без винятків видів діяльності цих установ. Проведені дослідження засвідчили, що під час проектування логістичних процесів в управлінні медичними установами потрібно також застосовувати структурний підхід до управління, суть якого полягає в розмежуванні управлінських функцій між конкретними особами. Розглянуто суть і важливість інноваційного логістичного підходу в управлінні мережею обласних медичних установ. 3'ясовано також, що завдяки логістиці можна значно покращити організацію діяльності медичних установ, підвищити рівень культури обслуговування осіб, що звернулися за допомогою до фахівців медичних установ. Запропоновано побудувати таку логістичну модель управління мережею обласних медичних установ, яка б вирішувала ключові організаційні проблеми, 3 якими сьогодні стикається безліч клієнтів цих установ.

\section{ЛITЕРАТУРА}

1. Барнатович С. В. Формування логістичної моделі управління діяльністю комунальних фармацевтичних підприємств в умовах менеджменту якості : автореф. дис. ... канд. фармац. наук : 15.00.01 ; Національний фармацевтичний університет. Хмельницький, 2011. 22 с.

2. Бенько I. Д., Бенько В. С. Оцінка ефективності системи управління запасами медичних установ : українська та світова практика. Всеукраӥнський науково-виробничий журнал "Інновачійна економіка". 2013. Випуск 1. С. 200-203.

3. Бенько I. Д., Сисюк С. В. Аналіз запасів медичних установ. Всеукраӥнський науково-виробничий журнал “Інноваційна економіка". 2013. Випуск 1. С. 267-270.

4. Вороненко Ю. В., Гойда Н. Г., Зозуля І. С., Латишев Є. Є., Михальчук В. М. Сучасні підходи до управління матеріальними ресурсами медичного закладу. Украӥнський медичний часопис. 2013. № 1. C. 19-22.

5. Каневський О. С., Кислий В. М., Ткачук І. С. Передумови застосування логістичних підходів у галузі медицини. Медищина транспорту України. 2005. № 5. С. 22-29. 
6. Котис Н. В., Ціщик Р. В. Аналіз доцільності запровадження логістичного менеджменту в діяльності закладів охорони здоров'я. Інфраструктура ринку. 2019. Випуск 33. С. 178-183.

7. Є. В. Мешко. Медична реформа: як зміниться “вторинка". Децентралізація дає можливості : вебсайт. URL: https://decentralization.gov.ua/news/11880 (дата звернення: 15.02.2020).

8. Національна стратегія реформування системи охорони здоров'я в Україні на період 2015-2020 років. Управління охорони здоров'я Чернігівської обласної державної адміністраиії : вебсайт. URL: http://uoz.cn.ua/strategiya.pdf (дата звернення: 15.02.2020).

9. Посилкіна О. В., Сагайдак-Нікітюк Р. В., Онищенко Я. Г. Управління утилізацією відходів у фармацевтичній галузі на логістичних засадах. Запорожский медицинский журнал. 2009. № 3. С. 120-124.

10. Стецюк В. 3., Іванова Т. П., Бабінцева Л. Ю., Ольхович Н. В., Лугін М. М., Фіногенов О. Д. Використання ЕRP-систем для медичних установ. Медична інформатика та інженерія. 2017. № 4. С. 44-47.

11. Філіпішин В. П. Застосування логістичних підходів у роботі лікувально-профілактичних закладів. Проблеми військової охорони здоров'я. 2015. Випуск 43. С. 16-23.

12. Ціщик Р. В. Аналіз застосування інноваційних логістичних підходів до діяльності медичних установ. Приазовський економічний вісник. 2019. Випуск 4 (15). С. 168-172.

13. Щербиніна М. Б., Скирда I. Ю. Формування та розвиток структурно-процесної організації в медичних установах. Гастроентерологія : збірник наукових праць. 2012. № 46. С. 48-56.

\section{Information about authors: Mykhalchuk V. M.,}

Doctor of Medical Sciences, Professor, Honored Health Worker of Ukraine, Head of the Department of Health Management National Medical Academy of Post-Graduate Education named after P.L. Shupik 9, Dorogozhyzkaja str., Kyiv, 04112, Ukraine

Kolomoyets A. V., Candidate of Medical Sciences, Director of "Medservice Group" 52, Dehtiarivska, 52, Kyiv, 04112, Ukraine 